\title{
Spouse-sharing and Experiences with Sexually Transmitted Diseases Among the Okun of Nigeria.
}

\author{
By \\ M.O. Osagbemi ${ }^{*}$, A.A. Adepetu ${ }^{1}$, A.O. Nyong ${ }^{1} \&$ A.S. Jegede ${ }^{2}$
}

\begin{abstract}
This paper examines the practice of spouse sharing and its influence on having multiple sex partners and self-reported STD experiences among the Okun people of Nigeria. It also examines the coping strategies of the people with respect to STDs. Primary data were collected through the administration of questionnaires to 1029 respondents (518 men and 511 women) and through focus group discussions. Respondents who participate in spouse sharing are more likely to have more sex partners simultaneously than those who do not, and multiple sexual partnering is a significant risk factor in the reporting of STD experience. Knowledge of the link between risky sexual practices involving multiple sexual partnerships and the prevalence of STDs is poor. Although most respondents are knowledgeable about the symptoms of STDs like gonorrhea and syphilis, and to a lesser extent HIV/AIDS, they are less informed about how best to prevent these diseases. The use of condoms is low among the men while a strong confidence is expressed in traditional medicine and self-protective practices with unproven efficacy. The study recommends the provision of more information, education and communication to expand knowledge of STDs, and the probable impact of spouse sharing in fueling the spread of STDs, including HIV/ AIDS.
\end{abstract}

Keywords: Spouse-sharing, Okun, Sexually Transmitted Diseases, sex partner, HIV/AIDS

1. Department of Geography and Planning, Faculty of Environmental Sciences, University of Jos. P. O. Box 2084 Jos, Plateau State, Nigeria. 2. Department of Sociology, Faculty of the Social Sciences, University of Ibadan, Ibadan, Oyo State, Nigeria 


\section{INTRODUCTION}

A major obstacle to controlling the spread of sexually transmitted diseases (STDs), including HIV/AIDS in sub-Saharan Africa is the absence of data on the sociocultural differences in sexual practices among indigenous populations. Knowledge of such practices is needed for the formulation and design of programmes aimed at promoting sexual and reproductive health in the light of sexual partners), can expose an average Okun person to STDs, including HIV/ AIDS.

Spouse sharing, locally referred to as ale or alase, is a common practice among the Okun people. This involves the acceptance of sexual relations between Okun men and the wives of their male kin. Men refer to their partners as alase while women refer to theirs as ale. Alase in Okun language literally means a cook. The name was probably derived from the fact that a man who maintains an affair with a kin's wife, besides sex affairs, enjoys the privilege of being cooked for by the woman. Usually, the man provides the woman with raw food items from his farm twice or three times a week. For non-farmers, it involves occasional gifts of money and other materials.

The main questions that this study seeks to answer are: What is the level of participation in spouse-sharing among the Okun people? Are there significant differences in the number of sex partners between those who are involved in spouse-sharing and those who are not? What is the prevalence of self-reported experience with STDs in the general population? Is there a correlation between self-reported STD experiences and the number of sex partners? How do the Okun people cope with the problem of STDs including HIV/AIDS?

The aim of the study is to contribute to the understanding of traditional practices that could influence the spread HIV/AIDS in Africa. It is hoped that this study will shed some lights on the relationships among spouse-sharing, number of sex partners and STD experiences, which can guide the formulation of programmes and direction for further enquiry into how to promote sexual and reproductive health among the Okun people.

\section{METHODS}

\section{Selection of Study Sites}


M.O. Osagbemi*, A.A. Adepetu, A.O. Nyong \& A.S. Jegede: Error! Main Document Only.Spousesharing and Experiences with Sexually Transmitted Diseases Among the Okun of Nigeria.

To select survey sites, a rapid reconnaissance of all communities within the Okun tribe was undertaken in March 1999 to identify where spouse-sharing was still prevalent. During the reconnaissance survey, the research team familiarized itself generally with the study area, determined the type of problems that may arise during the actual fieldwork, evolved strategies to tackle such problems, held crucial discussions with a wide range of people (village and ward heads, significant others, and local government staff) concerning the project, and thus notified and mobilised them for the project. Based on the reconnaissance survey, six communities ( 2 urban and 4 rural) in East Yagba Local Government Area of Kogi State, were selected for the survey. These are Isanlu and Mopa (urban), Ijowa, Efo Amuro, Ponyan and Ejuku (rural). The estimated populations of the selected communities are: Mopa, 9,354; Effo Amuro, 8,789; Ejuku, 9,371; Ponyan, 10, 211 and Isanlu (the headquarters of East Yagba Local Government Area) has a population of 24,662 (National Population Commission, 1991).

Isanlu has three banks, nine primary and four secondary schools. It has a general hospital and four private clinics. It is serviced by public utilities such as electricity and pipe borne water. The rural settlements can be divided into two: those along the major highway linking Lokoja, the capital of Kogi State to Ilorin, the capital of Kwara state. These include Mopa and Effo Amuro. Ponyan and Ejuku are fed by seasonal roads from the local government headquarters. While Mopa has a hospital, Ejuku, Effo Amuro and Ponyan each have a dispensary.

The Okun communities, like many other rural areas, have benefited from the family planning programmes of Kogi State Ministry of Health and that of the Planned Parenthood Federation of Nigeria. Officers of these programmes interviewed during the fieldwork reported periodic visits to the health centres at Isanlu to have talks on family planning issues with women attending antenatal clinics. The officers complained of lack of relevant information, education and communication materials to aid information dissemination. The locality does not have any elaborate programme of information dissemination on reproductive health.

\section{Questionnaire Administration}

While realizing that observations based on medical and laboratory examinations provide the best assessment of reproductive disease conditions, the costly nature of such exercises for studying 
disease situations in developing countries has been pointed out (Bleacher et al., 1993; Bath., 1995; Huda et al., 1995). Though accuracy between self-reported occurrence of disease and symptoms has been questioned (Murray et al., 1992), using questionnaires to obtain information on disease situations is still an attractive option for rapidly learning about the state of morbidity in the less developed countries (Halabi et al., 1992; Midthjell et al., 1992).

Sixteen field assistants ( 8 males and 8 females) were recruited and trained for one week in April 1999, on the rudiments of completing the survey questionnaire and the conduct of a focus group discussion. A questionnaire was developed with input from the community and was pre-tested in three communities and modifications were made in several sections. The final questionnaire contained 107 questions divided into four sections. Section 1 solicits information on the background characteristics of the respondents, while section 2 explores sexual relations of the respondents, particularly the practice of spouse-sharing. Section 3 contains questions designed to examine the respondents' knowledge and experience of STDs including HIV/AIDS, perception of risk and protective measures. Finally, section 4 elicits information on the respondents' knowledge of and use of condoms.

A multistage random sampling methodology was adopted to reach the eligible respondents. First, was the selection of enumeration areas (EAs) in each settlement, followed by the selection of households in the selected EAs, and the eligible respondents in the selected households? In each of the studied settlements, about $20 \%$ of the estimated EAs and 50\% of the estimated households in each EA were sampled. Between $15 \%$ and $17 \%$ of eligible respondents in each of the selected EAs were selected for a face-to-face interview. This generated a sample size of 1036 respondents, made up of 518 men and 518 women (See Table 1). The questionnaire survey was conducted in May 1999. Respondents and interviewers were matched by sex. Completed questionnaires were checked at the end of every day and those that were not properly filled were corrected by reinterviewing the respondents. The survey received a high level of support with a response rate of $99 \%$, only 7 persons refused to be interviewed. 
Table 1: Sampled settlements, enumeration areas, households and number of administered questionnaires (December 1998).

\begin{tabular}{|c|c|c|c|c|c|c|c|}
\hline $\mathrm{S} / \mathrm{n}$ & Settlement & $\begin{array}{c}1996 \\
\text { population }\end{array}$ & $\begin{array}{l}\text { No. of } \\
\text { EAs }\end{array}$ & $\begin{array}{l}\text { Sampled } \\
\text { EAs }\end{array}$ & $\begin{array}{l}\text { Number of } \\
\text { households }\end{array}$ & $\begin{array}{c}\text { Eligible } \\
\text { respondents }\end{array}$ & $\begin{array}{l}\text { Administered } \\
\text { questionnaire }\end{array}$ \\
\hline A & Isanlu & 22662 & 281 & 56 & 1176 & 3584 & 507 \\
\hline B & Мора & 10405 & 130 & 26 & 442 & 1281 & 205 \\
\hline $\mathrm{C}$ & Effo Amuro & 5790 & 84 & 17 & 255 & 760 & 117 \\
\hline $\mathrm{D}$ & Ejuku & 5644 & 75 & 15 & 180 & 482 & 82 \\
\hline $\mathrm{E}$ & Ponyan & 7371 & 105 & 21 & 273 & 788 & 125 \\
\hline F & Total & 51872 & 675 & 135 & 2382 & 6895 & 1036 \\
\hline
\end{tabular}

113 


\section{Focus Group Discussions}

Following the questionnaire survey, focus group discussions (FGDs) were held with participants who were selected to reflect important strata in each community. Each focus group discussion session had between 6 and 10 persons. Two group discussion sessions each, one with men and the other with women, took place in the selected rural settlements, while four took place in the urban area. A total of 12 group discussions were organized involving 82 participants. The focus group discussions were organized such that women conducted women's group and men conducted those of the men. The discussions focussed on the practice of spouse sharing, knowledge of STDs, and whether the informants perceived any link between spouse-sharing and STD experiences. Issues on coping strategies were also discussed. Participants spoke freely and exhaustively discussed every issue that was raised. A focus group discussion session lasted for an average of 3 hours. Each of the focus group discussion session was tape recorded. At the end of every session the research team spent some time to examine and discuss the outcome.

\section{Data Analysis}

The analyses of the FGD data began immediately with the first set of completed FGDs. The entire research team participated in the FGD data analysis. Each FGD team produced transcripts of their sessions and adopted a uniform procedure in the analysis of the generated data. The use of Ethnograph software greatly simplified the retrieving, coding and analysis of the FGD data. The quantitative data were subjected to descriptive analysis with respect to the sociodemographic characteristics of the respondents, level of involvement in spouse sharing, self-reported STD experiences and coping strategies. The data were further analysed using the Chi-square test and logistic regression.

\section{RESULTS AND DISCUSSION}

\section{Background Characteristics of the Respondents}

According to Table 2, most of the respondents were less than 36 years. A significant proportion (about $35 \%$ ) of the respondents had no formal education, with the women somewhat worse off than the men. About $66.6 \%$ of the men and $63.6 \%$ of the women had some formal schooling experience. 
Table 2: Selected background characteristics of the sampled respondents by sex

\begin{tabular}{|c|c|c|c|c|c|c|}
\hline \multirow{2}{*}{$\begin{array}{l}\text { Background } \\
\text { Characteristics }\end{array}$} & \multirow{2}{*}{\multicolumn{2}{|c|}{ Indicator Variables }} & \multirow[t]{2}{*}{$\mathbf{N}$} & $\begin{array}{c}\text { Male } \\
(\%)\end{array}$ & Female (\%) & $\begin{array}{l}\text { All } \\
(\%)\end{array}$ \\
\hline & & & & $(518)$ & $(511)$ & $(1029)$ \\
\hline \multirow{2}{*}{ Locality } & \multicolumn{2}{|l|}{ Urban } & 505 & 51.6 & 48.4 & 49.1 \\
\hline & \multicolumn{2}{|l|}{ Rural } & 524 & 52.8 & 47.2 & 50.9 \\
\hline \multirow{2}{*}{$\begin{array}{l}\text { Residence before age } \\
12\end{array}$} & & 385 & 42.3 & 32.5 & 37.4 \\
\hline & \multicolumn{2}{|l|}{ Rural Village } & 644 & 57.3 & 67.5 & 62.6 \\
\hline \multirow{2}{*}{ Age } & \multirow{2}{*}{\multicolumn{2}{|c|}{$\begin{array}{l}\leq 35 \text { years } \\
\geq 36 \text { vears }\end{array}$}} & 585 & 59.8 & 53.8 & 56.9 \\
\hline & & & 444 & 40.2 & 46.2 & 43.1 \\
\hline \multirow{2}{*}{ Educational status } & \multirow{2}{*}{\multicolumn{2}{|c|}{$\begin{array}{l}\text { No Formal Schooling } \\
\text { Some Formal Schooling }\end{array}$}} & 359 & 33.4 & 36.4 & 34.9 \\
\hline & & & 670 & 66.6 & 63.6 & 65.1 \\
\hline \multirow{6}{*}{ Media Exposure } & \multicolumn{2}{|c|}{ some Formal schooling } & 482 & 43.4 & 50.3 & 46.8 \\
\hline & Newspaper & Yes & 547 & 56.6 & 49.7 & 53.2 \\
\hline & \multirow{2}{*}{ Radio } & No & 141 & 11.6 & 15.9 & 13.7 \\
\hline & & Yes & 888 & 84.4 & 84.1 & 86.3 \\
\hline & \multirow{2}{*}{ Television } & No & 673 & 59.1 & 71.8 & 65.4 \\
\hline & & Yes & 356 & 40.9 & 28.7 & 34.6 \\
\hline \multirow{3}{*}{ Occupation } & \multirow{3}{*}{\multicolumn{2}{|c|}{$\begin{array}{l}\text { Paid Employment } \\
\text { Self Employment } \\
\text { Unemployed }\end{array}$}} & 350 & 67.4 & 35.4 & 34.0 \\
\hline & & & 494 & 49.8 & 46.2 & 48.0 \\
\hline & & & 185 & 17.6 & 18.4 & 18.0 \\
\hline \multirow{2}{*}{ Income } & \multirow{2}{*}{\multicolumn{2}{|c|}{ High }} & 252 & 31.8 & 17.2 & 24.5 \\
\hline & & & 777 & 68.2 & 82.8 & 75.5 \\
\hline \multirow{2}{*}{ Marital status } & \multicolumn{2}{|l|}{ Others } & 376 & 37.6 & 35.4 & 36.5 \\
\hline & \multicolumn{2}{|l|}{ Married } & 653 & 62.4 & 64.6 & 63.5 \\
\hline \multirow[t]{2}{*}{ Spouse-sharing } & \multirow{2}{*}{\multicolumn{2}{|c|}{$\begin{array}{l}\text { Involved } \\
\text { Not involve }\end{array}$}} & 672 & 65.6 & 64.9 & 65.3 \\
\hline & & & 357 & 34.4 & 35.4 & 34.7 \\
\hline
\end{tabular}

115 
The respondents were fairly exposed to the media, with a small difference between the men and the women (58\% and $54 \%$ respectively). The newspaper reading habit of the respondents was generally average, with about $53 \%$ reported reading or have someone read a newspaper to them at least once in a week. While most of the respondents $(86.3 \%)$ reported purposely listening to the radio at least once a week, only about 35\% reported watching a television programme at least once a week. Although an equal proportion of men and women listened to the radio, more men $(41 \%)$ reported watching television than women $(29 \%)$. This difference might be due to the timing of the television programmes, which usually coincides with time for preparation of evening meals for the family. The main reasons the respondents gave for not being fully exposed to the media are lack of possession or access $(82 \%)$ and lack of time $(16 \%)$.

About $34 \%$ of the sampled population were engaged in paid employment, but gender differentiation reveals the predominance of men $(67.4 \%)$ than women $(32.6 \%)$. Most of the respondents $(48.0 \%)$ were found in the traditional occupations, which include farming, petty trading, traditional processing, services, and arts and crafts. The remaining $18 \%$ of the respondents were categorised as unemployed. The average estimated annual income of the Okun was about US\$200.00, compared with a national annual average of US\$500.00 (World Bank, 2006). The overwhelming majority of Okun women $(82.8 \%)$ belonged to the low income category (those that earned below US\$200.00), compared with men (68.2\%).About two-thirds of the respondents were currently in unions, while the remaining $36.5 \%$ belong to the 'other' category, which includes never-married, widows, those separated and divorced.

\section{Spouse-sharing and Number of Sex Partners}

Two-thirds of the respondents (65.3\%) reported having ale or alase or practicing spouse-sharing. This category of people had 2014 sex partners among them, with an average of 3 partners per person. One-third of the respondent $(34.7 \%)$ who were categorised as not involved in spouse-sharing had a total of 438 sex partners among them, representing an average of 1.2 partners per person.

Table 3 contains information about reported number of sex partners and whether a respondent is categorised as involve or not involved in spouse-sharing practice. More than 8 out of every 10 persons identified as not practising spouse-sharing had one sex partner compared with only 3 out of 10 persons among those who practised spouse-sharing. About half (50.8\%) of those involved in 
M.O. Osagbemi*, A.A. Adepetu, A.O. Nyong \& A.S. Jegede: Error! Main Document Only.Spousesharing and Experiences with Sexually Transmitted Diseases Among the Okun of Nigeria.

spouse sharing had two sex partners compared with $14 \%$ among those not involved in the practice. About $19 \%$ of the respondents who were categorised as involved in spouse-sharing keep about three or more sex partners relative to only $2 \%$ of those not involved. Although some of those who reported non-involvement in spouse-sharing kept more than one sex partner, our data confirm the hypothesis that spouse-sharing significantly enhances multiple sexual partnerships among the Okun people.

Table 3: Number of sex partners and respondents' participation in spouse sharing among the Okun, 1999.

\begin{tabular}{|c|c|c|c|c|c|c|}
\hline \multirow{2}{*}{$\begin{array}{c}\text { Number of } \\
\text { Sex Partners }\end{array}$} & \multicolumn{3}{|c|}{ Respondents' Involvement in Spouse-Sharing } \\
\cline { 2 - 7 } & \multicolumn{2}{|c|}{ Involved } & \multicolumn{2}{|c|}{ Not involved } & \multicolumn{2}{|c|}{ Total } \\
\cline { 2 - 7 } & No. & $\%$ & No. & $\%$ & No. & $\%$ \\
\hline 1 & 205 & 30.5 & 300 & 84.0 & 505 & 49.1 \\
\hline 2 & 342 & 50.8 & 49 & 13.7 & 391 & 38.0 \\
\hline 3 and above & 125 & 18.6 & 8 & 2.2 & 133 & 12.1 \\
\hline Total & 672 & 100.0 & 357 & 100.0 & 1029 & 100.0 \\
\hline
\end{tabular}

$\chi^{2}=269.15, \mathrm{df}=2, p<0.001$

\section{Number of sex partners and STD Experience in the last 12 months}

About $22 \%$ of the respondents reported STD experience in last 12 months preceding the survey. Table 4 describes the relationship between number of current sex partners and percent reporting STD experience. The least STD experience in the last 12 months was reported among those categorised as having one sex partner $(10.1 \%)$ and the frequency of reporting STD experience increased with an increase in the number of sex partners of the respondents.

More people below 35 years $(27.3 \%)$ reported STD experience, than those above 35 years (18.3\%). There was no significant difference in the proportion reporting STD experience among respondents currently in unions and those who are not; there is also virtually no difference between those who lived in towns before age 12 and those who lived in the rural areas. The prevalence of STD experience $(27 \%)$ was highest among the respondents categorised as unemployed. 
Table 4: Percent distribution of respondents who self-reported STD experience by selected characteristics among the Okun People

\begin{tabular}{|c|c|c|c|}
\hline Characteristics & \multicolumn{2}{|l|}{ Indicator Variables } & $\begin{array}{l}\text { Percentage Reporting STD Experience in the } \\
\text { Last One Year }\end{array}$ \\
\hline \multirow{3}{*}{ Number of sex Partners } & \multirow{3}{*}{\multicolumn{2}{|c|}{$\begin{array}{l}\text { One } \\
\text { Two } \\
\text { Three and above }\end{array}$}} & 10.1 \\
\hline & & & 29.9 \\
\hline & & & 40.3 \\
\hline \multirow{2}{*}{ Age group } & \multirow{2}{*}{\multicolumn{2}{|c|}{$\begin{array}{l}\text { Less than } 36 \text { years } \\
36 \text { vears and above }\end{array}$}} & 18.3 \\
\hline & & & 27.3 \\
\hline \multirow{2}{*}{ Marital status } & \multirow{2}{*}{\multicolumn{2}{|c|}{$\begin{array}{l}\text { Married } \\
\text { Others }\end{array}$}} & 22.1 \\
\hline & & & 22.3 \\
\hline \multirow{2}{*}{ Locality status } & \multicolumn{2}{|l|}{ Urban } & 23.2 \\
\hline & \multicolumn{2}{|l|}{ Rural } & 20.2 \\
\hline \multirow{2}{*}{ Residence before age 12} & \multirow{2}{*}{\multicolumn{2}{|c|}{$\begin{array}{l}\text { Town } \\
\text { Rural village }\end{array}$}} & 20.4 \\
\hline & & & 21.1 \\
\hline \multirow{3}{*}{ Employment status } & \multicolumn{2}{|l|}{ Salaried work } & 20.3 \\
\hline & \multicolumn{2}{|l|}{ Self employed } & 21.7 \\
\hline & \multicolumn{2}{|l|}{ Unemployed } & 27.0 \\
\hline \multirow{2}{*}{ Income group } & \multirow{2}{*}{\multicolumn{2}{|c|}{$\begin{array}{l}\text { Low } \\
\text { High }\end{array}$}} & 25.4 \\
\hline & & & 12.3 \\
\hline Fducational status & \multirow{2}{*}{\multicolumn{2}{|c|}{$\begin{array}{l}\text { No formal schooling } \\
\text { Some form of schooling }\end{array}$}} & 22.0 \\
\hline Euucational status & & & 22.2 \\
\hline \multirow{6}{*}{ Media Exposure } & \multirow[t]{2}{*}{ Listen to radio } & Yes & 22.0 \\
\hline & & No & 22.2 \\
\hline & \multirow[t]{2}{*}{ Watch TV } & Yes & 34.0 \\
\hline & & No & 15.9 \\
\hline & \multirow[t]{2}{*}{ Read Newspaper } & Yes & 19.4 \\
\hline & & No & 25.3 \\
\hline
\end{tabular}


M.O. Osagbemi*, A.A. Adepetu, A.O. Nyong \& A.S. Jegede: Error! Main Document Only.Spousesharing and Experiences with Sexually Transmitted Diseases Among the Okun of Nigeria.

Based on our sample, there is a sharp difference in selfreported STD experience between high and low income earners, with the low income group reporting twice as much experience than the high income group. Our data reveal that most of those who reported STD experience within the last one year were largely from the low income group.

Education does not have any significant effect on the reporting of STD experience among the Okun people. Almost an equal proportion of those with formal education and those with no formal education reported STD experience. The results show that religion Muslims reported the highest incidence of STDs compared with Christians and Traditionalists. There were no differences in the percentage reporting STD experience among those exposed to the radio and those who were not. However, there was a slight variation in the reporting of STD experience among those exposed or not to television and the newspapers. This could be attributable to the graphic nature of STD campaigns in these media.

\section{Logistic Regression of STD experience}

The frequency of self-reported STD experiences varies not only with the number of sexual partners, but also with the individual's social, demographic, economic and cultural characteristics. This section examines the relative significance of all these factors in explaining the variability in self-reported STD experiences among the Okun people. We estimated 3 logistic regression models predicting the likelihood that a respondent will report STD experience in the last one year (see Table 5). 
Table 5: Logistic regression (odds ratio) predicting the probability of reporting STD experience by number of sex partners and socio-economic background characteristics.

\begin{tabular}{|c|c|c|c|c|c|}
\hline \multicolumn{2}{|l|}{ Variable } & Category & Model 1 & Model 2 & Model 3 \\
\hline \multicolumn{2}{|c|}{ Number of sex partners } & $\begin{array}{c}\text { One (Ref) } \\
\text { Two } \\
\text { Three and above }\end{array}$ & $\begin{array}{l}1.00 \\
3.90^{* * *} \\
3.41^{* * *}\end{array}$ & $\begin{array}{l}1.00 \\
7.60^{\star * *} \\
4.43^{* * *}\end{array}$ & $\begin{array}{l}1.00 \\
11.54^{* * *} \\
8.26^{* * *}\end{array}$ \\
\hline \multicolumn{2}{|c|}{ Locality Status } & $\begin{array}{c}\text { Rural } \\
\text { Urban (Ref) }\end{array}$ & & $\begin{array}{l}0.39^{* * *} \\
1.00\end{array}$ & $\begin{array}{l}0.50^{* *} \\
1.00\end{array}$ \\
\hline \multicolumn{2}{|c|}{$\begin{array}{llll}\begin{array}{l}\text { Residence } \\
\text { years }\end{array} & \text { before age } & 12 \\
& & \\
\end{array}$} & $\begin{array}{c}\text { Rural village } \\
\text { Township (Ref) }\end{array}$ & & $\begin{array}{l}0.85 \\
1.00\end{array}$ & $\begin{array}{l}0.96 \\
1.00\end{array}$ \\
\hline \multicolumn{2}{|c|}{ Sex of respondents } & $\begin{array}{c}\text { Female } \\
\text { Male (Ref) }\end{array}$ & & $\begin{array}{l}0.84 \\
1.00\end{array}$ & $\begin{array}{l}0.72 \\
1.00\end{array}$ \\
\hline \multicolumn{2}{|l|}{ Age group } & $\begin{array}{c}35 \text { years and below } \\
36 \text { years and above } \\
\text { (Ref) }\end{array}$ & & $\begin{array}{l}2.29^{* * *} \\
1.00\end{array}$ & $\begin{array}{l}1.76^{*} \\
1.00\end{array}$ \\
\hline \multicolumn{2}{|c|}{ Educational status } & $\begin{array}{c}\text { No formal } \\
\text { schooling } \\
\text { Some schooling } \\
\text { (Ref) }\end{array}$ & & $\begin{array}{l}0.27^{* * * *} \\
1.00\end{array}$ & $\begin{array}{l}0.24^{* * *} \\
1.00\end{array}$ \\
\hline \multirow[t]{3}{*}{$\begin{array}{c}\text { Media } \\
\text { exposure }\end{array}$} & Newspaper & $\begin{array}{c}\text { Yes } \\
\text { No (Ref) }\end{array}$ & & $\begin{array}{l}0.86 \\
1.00\end{array}$ & $\begin{array}{l}0.96 \\
1.00\end{array}$ \\
\hline & Radio & $\begin{array}{c}\text { Yes } \\
\text { No (Ref) }\end{array}$ & & $\begin{array}{l}2.6^{*} \\
1.00\end{array}$ & $\begin{array}{l}2.75^{* *} \\
1.00\end{array}$ \\
\hline & Television & Yes & & $0.23^{* * *}$ & 0.22 \\
\hline
\end{tabular}




\begin{tabular}{|c|c|c|c|c|}
\hline & No (Ref) & & 1.00 & 1.00 \\
\hline Occupational Status & $\begin{array}{c}\text { Paid employment } \\
\text { Self employment } \\
\text { (Ref) } \\
\text { Unemployed }\end{array}$ & & $\begin{array}{l}2.45^{* *} \\
1.00 \\
1.72^{*}\end{array}$ & $\begin{array}{l}1.98^{*} \\
1.00 \\
1.32\end{array}$ \\
\hline Annual Income & $\begin{array}{c}\text { Low } \\
\text { High (Ref) }\end{array}$ & & $\begin{array}{l}5.47^{* * *} \\
1.00 \\
\end{array}$ & $\begin{array}{l}4.77^{* *} \\
1.00\end{array}$ \\
\hline Marital Status & $\begin{array}{c}\text { Married } \\
\text { Others (Ref) }\end{array}$ & & $\begin{array}{l}1.19 \\
1.00 \\
\end{array}$ & $\begin{array}{l}1.12 \\
1.00 \\
\end{array}$ \\
\hline Knowledge of HIV/AIDS & $\begin{array}{c}\text { High } \\
\text { Medium (Ref) } \\
\text { Low }\end{array}$ & & & $\begin{array}{l}1.32 \\
1.00 \\
.27^{* * *}\end{array}$ \\
\hline Perception of Risk & $\begin{array}{c}\text { Yes } \\
\text { No (Ref) }\end{array}$ & & & $\begin{array}{l}1.31 \\
1.00\end{array}$ \\
\hline $\begin{array}{l}\text { Using a Method to Avoid } \\
\text { STDs and HIV / AIDS } \\
\text { Constant } \\
\text {-2 log likelihood }\end{array}$ & $\begin{array}{c}\text { Yes } \\
\text { No (Ref) }\end{array}$ & $\begin{array}{c}-1.74 \\
468.51\end{array}$ & $\begin{array}{l}-1.98 \\
441.74\end{array}$ & $\begin{array}{l}0.50^{* *} \\
1.00 \\
-2.18 \\
424.56\end{array}$ \\
\hline
\end{tabular}

${ }^{*} \mathrm{P}<0.05$ ** $\mathrm{P}<0.01$ *** $\mathrm{P}<0.001$

121 
Model 1 shows the performance of the variables that capture the differences in the number of sex partners. There is a positive relationship between the number of sex partners and the frequency of self-reporting of STD experiences, although this relationship is not linear. The likelihood of reporting STD experience among those with two partners was about 4, while that of more than 2 partners was about 3, compared with those with only one partner. When background variables such as locality, childhood residence, sex, age, educational background, media exposure, occupation, income, and marital status were included (model 2) the odds ratio of reporting STD experience among those with two partners increased to about 7, that of those with three or more partners increased to about 4 , compared with those with only 1 partner.

The less educated respondents had a lower odds ratio of reporting STD experiences than those who had formal education. Respondents who were exposed to television and newspapers were less likely to report STD experience than those who were not exposed to it. Contrary to our expectations, respondents who lived in rural areas before age 12 and those of rural origins were less likely to report STD experiences than those of urban residence and origin. With the low media coverage in the rural areas, particularly access to television and newspapers, one would have expected the reverse to be the case. The background variables that significantly increased the likelihood of exposure to STD included exposure to the radio, being in paid employment, being unemployed, low income, and being categorised as young (the age group 35 years and below).

Controlling for the full set of variables in Model 3, with the addition of three knowledge variables - knowledge of HIV/AIDS, perception of the risk of contracting HIV/AIDS and currently using a method to avoid STDs including HIV/AID - did not significantly alter the relationship between number of sex partners and STD experience. Having more than one sex partner remains a significant predictor of reporting STD experience among the Okun. The results clearly suggest that the practice of spouse-sharing enhances the incidence of STDs in the population.

\section{Coping Strategies}

The various strategies employed by the people to avoid contracting STDs, including HIV/AIDS, are presented in Table 6. Forty-seven percent of the respondents reported that they were using a method or that they were currently doing something to avoid contracting STDs. Keeping one faithful partner or non-participation 
M.O. Osagbemi*, A.A. Adepetu, A.O. Nyong \& A.S. Jegede: Error! Main Document Only.Spousesharing and Experiences with Sexually Transmitted Diseases Among the Okun of Nigeria.

in the practice of spouse-sharing was the most adopted strategy $(64.3 \%)$, followed by using protective drugs or charms (16.4\%). Many respondents believed in the use of specially prepared traditional medicine as means of protection against STDs, including HIV/ AIDS. Some of these charms are prepared as rings and waist bands, and it is generally believed that if one wears such a ring or ties the waist band, he or she becomes immune to STDs, including HIV/ AIDS. The use of condoms ranked very low, with less than $7 \%$ of the respondents using them.

Table 6: Percentage distribution of respondents by reported coping strategies among the Okun

\begin{tabular}{|l|l|c|c|}
\hline & \multicolumn{1}{|c}{ Coping Strategies } & \multicolumn{2}{c|}{ Respondents } \\
\hline & & No & $\%$ \\
\cline { 2 - 3 } A & Protective behaviour & $\mathbf{4 8 3}$ & $\mathbf{4 6 . 9}$ \\
2 & Abstinence & 44 & 9.1 \\
& One faithful partner /None & 310 & 64.3 \\
3 & participation in spouse-sharing & & \\
4 & Use of condom & 32 & 6.6 \\
& Protective Drugs or Rings & 79 & 16.4 \\
B & Treatment seeking behaviour & $\mathbf{2 2 7}$ & $\mathbf{2 2 . 1}$ \\
1 & Visit to the health centre & 100 & 44.2 \\
2 & Visit to herbalist & 86 & 38.0 \\
3 & Self medication & 41 & 17.8 \\
\hline
\end{tabular}

Because of its generally wide acceptance and its reported efficacy in protecting against STDs, including HIV/ AIDS (Williamson 1992), more attention was devoted to the use of condoms in the survey questionnaire. While a few of the respondents reported using condoms, a larger proportion (30\%) which cuts across all ages was aware of its existence. A third of the respondents had learned about condoms mainly through their friends, while about $20 \%$ did so through conversations on the streets, and $12 \%$ through the radio. Written or printed materials like posters $(3 \%)$, booklets $(6 \%)$ or newspapers $(7 \%)$ were less important sources of information for the respondents. This questions the effectiveness of the national campaign on family planning and safe sex through the use of posters, flyers and the print media. Among the respondents, the condom is variously known by local names such as sitokin or socks $(62 \%)$, raincoat $(21 \%)$, and fila baba or grandfather's cap (10\%).

A gender differentiation in the sources of information on condoms showed a marked difference between men and women. 
Men received information about condom mainly through informal sources, in particular their friends $(14 \%)$, people on the streets $(11 \%)$ and relatives $(7 \%)$. Women, on the other hand, largely depended on formal sources such as through health staff $(35 \%)$, the radio $(12 \%)$, newspapers $(6 \%)$ and booklets (5\%). Virtually all women who learnt of condoms through health officials admitted that this was during their antenatal and post-natal clinics.

Knowledge of the protection provided by condoms against STDs was very low. Most of the respondents (84\%) presumed that condoms are used to prevent conception, while less than $20 \%$ believed that it could prevent STDs. On why the male respondents did not use condoms, about $46 \%$ stated that the use of condoms might offend their partners, $13 \%$ believed that the AIDS virus is implanted in condoms, while $12 \%$ stated that the use of condoms was against their religion.

Regarding treatment seeking behaviour, almost a half of the respondents who reported STD experience in the last one year reported at least a visit to a health centre for consultation with medical personnel, 38\% consulted with traditional herbalists, and the remaining $18 \%$ practised self-medication were yet to be treated. Those who resorted to self-medication mainly used tetracycline as revealed during the focus group discussion. The belief in the efficacy of tetracycline is summarized by an informant and supported by other men during the focus group discussion.

Anytime one suspects that he or she has STD, just immediately take elayameji (ie two colours, local name for tetracycline). That drug is very strong; it can cure all STD problems. Better still, if you are not sure of the woman, you take the drug before the act and you are protected. Like me I always have it with me.

\section{DISCUSSION}

The study revealed that spouse-sharing is still an important way of life among the Okun people as about 7 out of every 10 sexually active persons reported having at least one ale or alase. The study revealed a significant difference in the average number of sex partners among those who participate in spouse-sharing (3.0) and those who do not (1.2). About $22 \%$ of the sampled respondents reported STD experience in the year preceding the survey. Our analysis of the relationships between number of sex partners and self 
M.O. Osagbemi*, A.A. Adepetu, A.O. Nyong \& A.S. Jegede: Error! Main Document Only.Spousesharing and Experiences with Sexually Transmitted Diseases Among the Okun of Nigeria.

reported STD experience revealed that after controlling for all the variables in the data set, having more than one sex partner remains a significant risk factor in contracting STD among the Okun. This is an indication of the health risk of spouse-sharing, particularly in the light of HIV/AIDS. Studies have shown a close association between the incidence of STDs, including HIV/AIDS, and simultaneous keeping of multiple sex partners (Reiss and Leik, 1989; Aral et al., 1991; Olaleye, 2003; Jegede, 2006).

Both the quantitative and qualitative data revealed that sexually transmitted diseases constitute an important health problem in the Okun communities, probably because of the practice of spousesharing. The people are knowledgeable about common STDs such as gonorrhoea and syphilis, and could describe their symptoms. However, there is relative lack of knowledge about other STDs. The conclusion that may be drawn in this respect is that when the people described their STDs by using one of the Okun medical terms for STDs, such as atosin (gonorrhoea) and syphilis (elewo), they may be referring to a large variety of complaints and syndromes.

Over the years, the Okun people have evolved many strategies for coping with the problem of STDs. Preventive means adopted include: abstinence, having one faithful partner and nonparticipation in spouse-sharing, use of condoms and use of protective drugs and traditional charms. For treatment seeking behaviour, they visit orthodox medical centres, consult with herbalists, and self medicate. The efficacy of some methods of prevention and treatment of STDs, particularly with the advent of HIV/AIDS, is questionable. For instance, the efficacies of charms, use of antibiotics before sexual encounters, among others, are questionable preventive methods. However, the fact that some people believe in them to prevent and even cure STDs, including AIDS, points to the need for more sex education, particularly in the prevention and management of STDs. The conclusion that may be reached is that the local perceptions and expectations about the treatment of STDs, including HIV/AIDS, differ considerably from the ones shared by orthodox medical practitioners. The people's beliefs about traditional medicine do affect their treatment-seeking behaviour and disease management, especially if the use of traditional medicines results in long term trials and possible errors before a patient decides to seek orthodox medical assistance.

Since the use of condoms for the prevention of STD, including AIDS, is still generally low (Adewole et al., 2002; Oye-Adeniran et al., 
2003), encouraging the practice of having one sex partner and the non-participation in spouse-sharing is an effective strategy for preventing STDs (Caldwell et al., 1989). It is also the most veritable strategy for the eventual eradication of spouse-sharing among the Okun people. Perhaps one of the most important findings of this study is that respondents who reported using a method or currently doing something to avoid STDs, including HIV/AIDS, were significantly less likely to report STD experience. This underscores the need to promote protective practices as an urgent step to reduce the prevalence of STDs and forestall possible AIDS epidemic against the background of spouse-sharing and multiple sexual partnering in the Okun communities.

\section{Recommendations}

Having established the links among spouse-sharing, multiple partnership and STDs, the need to re-examine the significance of this practice becomes urgent. This is especially so now that the AIDS is spreading rapidly in different parts of the country (UNAIDS 2005). It is with this in mind that the following policy recommendations are made:

1. Concerted effort should be made to increase the level of awareness of the risk of spouse-sharing to the reproductive health of the community, in the light of STDs and HIV/AIDS. The local people should be educated about the link between number of sex partners and the risk of contracting STDs.

2. At risk behaviour of people should be questioned. Special attention should be paid to the risk that the average Okun person is exposed to by having sexual relations with ale or alase. Alternatives for behaviour should be sought at the community level. Thus, messages about protective measures should offer at least different alternatives: limiting oneself to one faithful partner and non-involvement in ale/alase practice.

3. Persuading people to abandon an age long practice may take sometime to accomplish, and the time on our hands is limited based on reports that HIV / AIDS is spreading rapidly in Nigeria (Orubulaye et al., 1991; UNIADS, 2005). As an immediate measure against the further spread of STD and a possible HIV/AIDS epidemic, the use of condoms should be encouraged because of its efficacy in protecting against STDs (Barer and Ravindran, 1995). 
M.O. Osagbemi*, A.A. Adepetu, A.O. Nyong \& A.S. Jegede: Error! Main Document Only.Spousesharing and Experiences with Sexually Transmitted Diseases Among the Okun of Nigeria.

4. People should be advised to seek treatment for STDs in the hospitals and from qualified medical personnel to avoid complications associated with prolonged treatment and undetected and untreated diseases. This is more so because local knowledge of the varieties of STDs is still limited and the efficacy of the local treatment is unknown.

\section{ACKNOWLEDGEMENT}

We gratefully acknowledge the financial support of the Special Programme of Research, Development and Research Training in Human Reproduction, World Health Organization (Award no. BSDA-95080-Nigeria). We would like to express our appreciation to the staff of the East Yagba Local Government Area (LGA) of Kogi State, particularly Mrs. Omoniwa, the Coordinator of the Family Planning Programme, for their cooperation and support. We are grateful to the staff of National Population Commission at Isanlu who helped in the recruitment of field assistants. We are also grateful to B.O.M. Joseph, Yemisi Aliu of Centre for Children in Crisis (CENCHIC) Jos and Omomoh Emmanuel of Population, Environment and Development Agency Jos, for their encouragement and editorial assistance.

\section{REFERENCES}

Abrahamson, P.R. and Herdt, G. (1990) The Assessment of Sexual Practices Relevant to the Transmission of AIDS: A Global Perspective. The Journal of Sex Research (27), 215-232.

Adewole IF, Oye-Adeniran BA, Iwere N, Oladokun A, Gbadegesin A and Babrinsa LA (2002) Contraceptive usage among abortion seekers in Nigeria. West Africa Journal of Medicine, 21(2): 112-114.

Bath, C. J. and Cleland J. (1995) "Self-reported Symptoms of Gynecological Morbidity and their Treatment in South India. Studies in Family Planning 26,4:203-216.

Belched, D.W., A.K. Neumann, F.K. Wurapa, and I.M. Lourie (1976) Comparison of Morbidity Interviews with a Health Examination Survey in Rural Africa. American Journal of Tropical Medicine and 
Hygiene 25, 5: 751-758.

Berer M. and Ravindran T.K.S. (1995) Pregnancy, Birth Control, STDs and AIDS: Promoting Safer Sex. Reproductive Health Matters 5: 7-12

Bleacher, J.C., Adolph, V.R., Dillon, P.W., and Krummel, T.M. (1993)

Fetal tissue repair and wound healing. Dermatol. Clinics, 11:677-683.

Careal, M., Cleland, J., Deheneffe, J and L. Adeokun, (1991) Research on sexual behaviour that transmits HIV: The GPA/WHO collaborative surveys-preliminary findings

Caldwell JC, Caldwell P \& Quiggin P (1989) The Social Context of AIDS in sub-Saharan Africa. Population and Development Review, Vol. 15, No. 2, 185-234

Dallabetta, G., Field M.L., Laga, M., and Islam Q.M. STDs (1996) Global burden and Challenges for control. Arlington Virginia, Family Health International. $22 \mathrm{p}$.

Halabi, Susan, Huda Zurayk, Rana Awaida, May Darwish, and Bassem Saab. 1992. Reliability and validity of and proxy reporting of morbidity data: A case study from Beirut, Lebanon." International Journal of Epidemiology 21,3:607-612.

Huda, Z., Hind, K., Nabil, Y., Olfia, K., and Mahinaz E. (1995). Comparing Women's Reports with Medical Diagnoses of Reproductive Morbidity Conditions in Rural Egypt. Studies in Family Planning 26,1:14-21

Jegede, A. S. (1998). African Culture and Health, Stirling-Horden, Ibadan.

Jegede AS (2005) A qualitative investigation of cultural context of HIV transmission in two selected Yoruba communities of Southwestern Nigeria. Journal of Genito-urinary Medicine, vol. 5(1\&2): $16-24$.

Midthjell, Kristian, Jostein Holmen, Arild Bjorndal and Per G. LundLarsen. 1992. "Is questionnaire information valid in the study of chronic disease such as diabetes? The Nord-Trondelag diabetes study. Journal of Epidemiology and Community Health 46:537-542.

Murray, Christopher J.L. and Lincoln C. Chen. 1992. Understanding morbidity change. Population and Development Review 18,3: 481-503. 
M.O. Osagbemi*, A.A. Adepetu, A.O. Nyong \& A.S. Jegede: Error! Main Document Only.Spousesharing and Experiences with Sexually Transmitted Diseases Among the Okun of Nigeria.

Olaleye DO (2003) The Fingerprints of a Monster: Message from the Dead to the Living. Inaugural Lecture, University of Ibadan.

Orobuloye I.O., J.C. Caldwell and P. Caldwell. 1991. Sexual networking in the Ekiti District of Nigeria. Studies in Family Planning 22: 1 - 73 .

Oye-Adeniran, BA, Adewole IF, Umoh AV, Iwere N, Dipeolu O and Obilade TT (2003) Contraceptive Prevalence at the Community Level in Southwestern Nigeria. Obstetric Journal of Hospital Medicine, 13(3-4): 49-53.

Reiss, I. L., \& Leik, R. K. (1989). Evaluating strategies to avoid AIDS: Numbers of sexual partners versus use of condoms. Journal of Sex Research, 26, 411-433.

UNAIDS/WHO (2002) AIDS Epidemic Update, December 2002. ISBN 92-91173-253-2.

UNAIDS (2005) The HIV/AIDS Epidemic in Nigeria. UNAIDS, [Available:www.aegis.com/files/synergyaids/Nigeria. Access: 23 July, 2007]

Vanguard (1999) HIV/AIDS Control: Lesson from Uganda. Tuesday 23 February pp.10 Lagos

Williamson, N.E. 1992. Delivering family planning in the era of AIDS and STDs Family Planning, The Proceedings of the IPPF Family Planning Congress, New Delhi.

World Bank (2006) Nigeria Country Profile. Washington D.C: Oxford University Press. 


\section{APPENDIX A: Statistical Model and Explanatory Variables}

The logistic regression was used to predict self-reported STD experiences among respondents. The model generally took the form:

Where:

$$
\operatorname{In}[Y /(1-Y)]=X
$$

$Y$ denotes the probability of outcome variable, $[Y /(1-Y)]$ representing the odds of the outcome variable (for example, reporting STD experience in the last one year as opposed to not reporting STD experience).

$X$ is a vector of explanatory variables, and

is a vector of regression coefficients, which depending on the sign, represents increments or reductions in the log odds of reporting STD experience. For a specific predictor variable, the exponent of the estimated coefficient gives the odds ratio of the outcome variable compared with that of the reference group or category.

The explanatory variables used in the model are as follows: number of sex partners, spouse sharing, knowledge of HIV/AIDS, perception of risk of STD, education, media exposure, occupation, income, sex, locality status, residence before age 12, age and marital status. The results were interpreted in terms of odds ratios and associated $p$ values. 